\title{
Revision of Heteroblemma gen. nov. (Dissochaeteae - Melastomataceae) from Malesia and Vietnam
}

\author{
R. Cámara-Leret ${ }^{1}$, J.W.A. Ridder-Numan ${ }^{1}$, J.F. Veldkamp ${ }^{1}$
}

\section{Key words}

Heteroblemma

Malesia

Medinilla

Melastomataceae

taxonomy

Vietnam

\begin{abstract}
A taxonomic revision is presented of the new genus Heteroblemma (Dissochaeteae-Melastomataceae) formerly a section of Medinilla which occurs in Malesia and Vietnam with 14 species, 3 new, and 11 new combinations. Descriptions, illustrations, a key, and an index to collectors are provided.
\end{abstract}

Published on 18 October 2013

\section{INTRODUCTION}

Blume (1849) distinguished a number of sections in Medinilla Gaudich. (Melastomataceae), which have not been accepted by later authors, e.g. Cogniaux (1891) and Bakhuizen van den Brink Jr (1943, 1946, 1947). However, a very peculiar one is sect. Heteroblemma Blume with (then) as the only species M. alternifolia Blume. Stapf (1895a, b) already noted that the latter is "a well-characterised group ... differs from the other species of Medinilla very strikingly in habit; a difference which is brought about by the long and slender branches, which climb by means of aerial roots, and by the alternate, generally long-petioled, and often large leaves, the transverse venation is more marked than in most Medinillae".

Curiously, in between the illustrations for his new species belonging to Heteroblemma (t. 2411, 2417) he described the genus Hederella Stapf with 4 species (now Catanthera F.Muell.) (t. 2415,2416 ) but did not note the similarity or differences between this and Heteroblemma.

A survey of the infra-familiar classification was given by Renner (1993). She included Catanthera, Kendrickia Hook.f., and Medinilla in the Miconieae DC. with 38 genera and c. 2200 species. Later (Clausing \& Renner 2001a) the Dissochaeteae Triana were recognised as distinct with 380 species in 9 genera among which Catanthera, Kendrickia and Medinilla sect. Heteroblemma.

Medinilla has opposite or whorled leaves, which usually are more or less isophyllous. However, in Heteroblemma the leaves are so strongly anisophyllous that they appear to be alternate. Apparently only in very young shoots one minute member of the pair is still present (e.g. in SF 32755 (Corner), Veldkamp 7902), but generally in older ones this has totally disappeared or has become invisible because of the overgrowth by mosses and humus. Only rarely some leaves are opposite, showing the plesiomorphic state.

Over the years other species with such leaves have been described. They all share a curious woody stele. In Medinilla it is terete in transverse section, but in Heteroblemma (and

\footnotetext{
${ }^{1}$ Naturalis Biodiversity Center, P.O. Box 9517, 2300 RA Leiden, The Netherlands; corresponding author e-mail: jef.veldkamp@naturalis.nl.
}

Kendrickia from Sri Lanka with isophyllous, opposite leaves; see Bremer 1988) it is more or less stellately lobed (see Fig. 1). In Catanthera (incl. Phyllapophysis Mansf.) the lobes are further broken up into lobed bodies. Thus Catanthera, Heteroblemma, and Kendrickia are united by a complex wood anatomical synapomorphy that appears to relate to their growth form (Clausing \& Renner 2001a). This remarkable 'anomalous' anatomy is discussed by Van Vliet (1981) and summarised by Clausing \& Renner (1992a: 55-56). In brief, after a closed cylinder of secondary xylem has been formed in young stems, the cambium starts to produce parenchymatous tissue at usually four equidistant positions (no doubt due to the decussate leaves). Continuing production of xylem between these meristematic patches results in a radiate, sometimes cloverleaf-shaped xylem.

Heteroblemma never has coroniform hairs, while these are usual in Catanthera. Kendrickia is glabrous.

In Heteroblemma the sessile fascicles of flowers are directly placed on opposite tubercles on the stem, while in Catanthera the inflorescences are axillary to cauliflorous, and often umbellate and pedunculate. Growth thus seems to be monopodial, which appears to be exceptional, for in Medinilla it apparently is sympodial. In Kendrickia the flowers are solitary or in umbelshaped few-flowered terminal cymes, growth here is therefore also sympodial.

The 8 stamens of Heteroblemma and Kendrickia are equal in shape, size, and development, while in Catanthera they are alternatingly 4 long and 4 short, the latter often staminodial.

The extra-ovarian pockets extend nearly to the base of the ovary, while in Medinilla they are said to reach at most to its middle (Bakhuizen van den Brink Jr 1943, 1946, 1947: 41, key lead 7b).

Although especially Kendrickia is morphologically and phytogeographically quite different from the other two, the three form a monophyletic clade when their $n d h F$ sequences are analysed (Clausing \& Renner 2001a).

The combination of these features clearly sets Heteroblemma apart, and one might imagine a line from Medinilla s.s. to Kendrickia through Heteroblemma to Catanthera. As these are considered to be distinct genera, sect. Heteroblemma should 


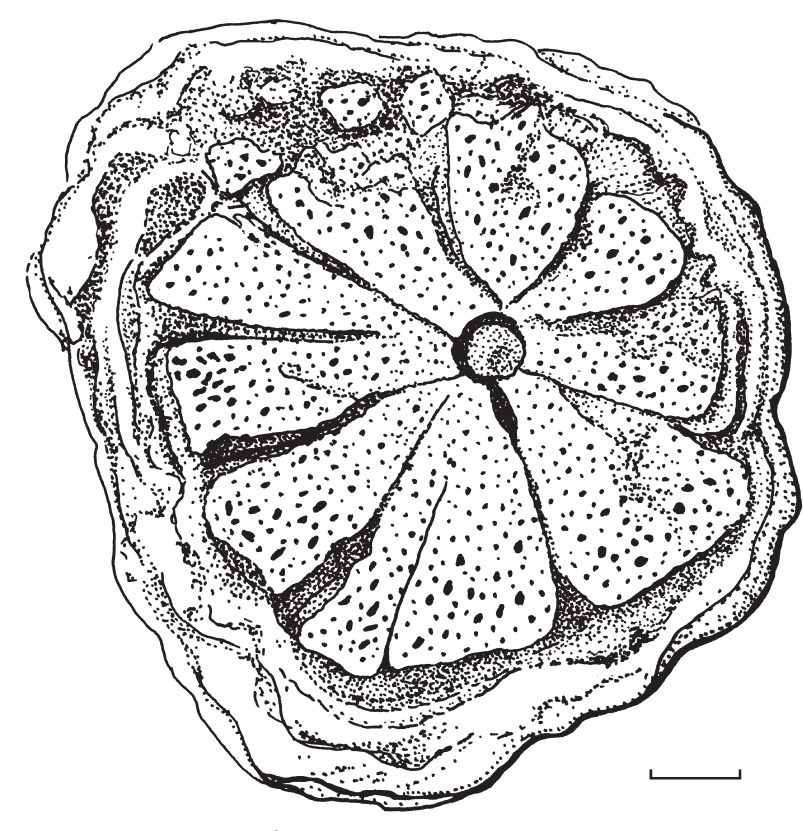

WALSMIT SACHS 2012

Fig. 1 Heteroblemma alternifolium (Blume) Cámara-Leret, Ridd.-Num. \& Veldk. Transverse section through stele (Achmad 355, L). - Scale bar $=$ $1 \mathrm{~mm}$.

be, too. The name Blume gave to the section appears to be indicative of this, also. He gave no explanation for its meaning, but clearly it is derived from the Greek words hetero and blemma: 'different looking'.

Bakhuizen van den Brink Jr $(1943,1946,1947)$ in his revision of the Indonesian Melastomataceae based on material present in Leiden ( $L$ ) and Utrecht ( $U$, now in Leiden) casually mentioned the section (p. 177), but did not maintain it, as he regarded the characters as too inconstant. He included $M$. alternifolia and two new species clearly related to it in sect. Heteromedinilla Bakh.f., which name is therefore superfluous.

In 1977 JRN, in a course on taxonomic botany supervised by JFV, and Bakhuizen van den Brink Jr prepared a manuscript based on the Leiden holdings. Due to duties elsewhere it remained unedited and unpublished. Since then some species from Borneo were published by Regalado (1990). The first author, RCL, as part of the requirements of a Master's Degree of the Leiden University, has now completed the revision.

The genus as circumscribed here occurs in Vietnam (3 spp.), Peninsular Malaysia (1), Sumatra s.I. (3), Borneo (11), Celebes (1), and New Guinea (1). Curious is the absence in Thailand and Cambodia, Java (erroneously mentioned by Regalado 1990: 16), the Lesser Sunda Islands, the Philippines, and the Moluccas.

Labels indicate the plants to be epiphytes, once as an epilith. Several species have been noted to grow near rivers or in periodically flooded areas and may be at least facultative rheophytes (e.g. H. capillipes: Zainudin 4611). These are plants that occur in river beds which experience flash floods (banjir) and have special adaptations to such an event: extensive root systems, tenacious branches, streamlined leaves, etc. In this case the numerous vegetative rootlets with which the plants are attached to their hosts or rocks can be expected to prevent the plants to be swept away. None were mentioned by Van Steenis in his studies regarding rheophytes $(1981,1987)$. Most species are rarely collected, either because they are indeed rare and local, or because they grow way up in the canopy, and so are only occasionally seen and within reach, or grow in dangerous places along riverbeds.
As is usual in the family, petals, and stamens are easily lost in the drying and mounting processes, so specimens often only have undeveloped hypanthia. Fortunately, contrary to the situation in Catanthera, the leaves appear to be quite diagnostic and useful in the delimitation of the taxa. However, when there are only a few collections it is not always clear whether two different leaf forms belong to the same taxon or represent two distinct ones (see the notes under $H$. capillipes and $H$. loratum).

\section{MATERIAL AND METHODS}

Herbarium collections from AAU, BM, C, E, K, L, M, SAR, and SING were examined.

Because flower parts elongate after opening, for the measurement of the length of petals, filaments, anthers, and style mature but still closed or nearly open buds were studied after briefly simmering in water.

\author{
Heteroblemma (Blume) Cámara-Leret, Ridd.-Num. \& Veldk., \\ stat. nov.
}

Medinilla Gaudich. sect. Heteroblemma Blume, Mus. Bot. 1 (1849) 19. Type: Medinilla alternifolia Blume [ $\equiv$ Heteroblemma alternifolium (Blume) Cámara-Leret, Ridd.-Num. \& Veldk.].

Woody, branching monopodially, climbing with numerous adventitious roots. Hairs never coroniform. Branches terete, sometimes grooved, often pubescent when young; the older ones, in transverse section, with a lobed stele and a round marrow channel. Leaves long-petiolate, apparently alternate, rarely some opposite, blades 3-9-plinerved, with or without a marginal vein, secondary venation scalariform (rarely absent), more or less elevated on the lower surface. Flowers in opposite, cymose bundles, 1-many together depending on the age of the stem, ramiflorous to cauliflorous on tubercles, 4-merous. Hypanthium broadly to narrowly campanulate, calyx inconspicuous or conspicuous, sepals sometimes represented by short teeth. Petals broadly falciform to triangular, somewhat fleshy. Stamens 8, equal in shape and size; plectrum triangular, rarely rectangular, somewhat wrinkled, auriculate, shortly stalked to sessile, passing into the ventral ridge along the middle of the anther. Ovary 4-locular, obconical, extra-ovarian chambers 8, reaching nearly to the base of the hypanthium. Fruits glabrous to hirsute, often filled with a jelly-like substance, calyx remnants persistent or absent in fruit.

Distribution - 14 species in Malesia (Peninsular Malaysia, Sumatra s.I., Borneo, Celebes, New Guinea) and Vietnam.

\section{MORPHOLOGY}

\section{Habit}

In contrast to Medinilla, in Heteroblemma all species are woody root climbers. Root climbing has evolved in 9 genera in the Palaeotropics and in 9 or 10 in the Neotropics (Clausing \& Renner 2001a: 46). Adventitious roots provide a firm hold on supporting trunks and branches but also on rocky boulders along streams. Other than support, adventitious roots simultaneously allow for the up-take of the stem run-off, which contains many nutrients leached from the canopy (Nadkarni 1981). Apparently, in age the roots may die off and the stems become free from the hosts, field labels then report the specimens as vines or lianas, sometimes of considerable length e.g. c. $25 \mathrm{~m}$ in H. coronatum.

Most species are found growing on trees on primary or secondary dipterocarp forests, on swamp forests, some appear to be restricted to limestone hills ( $H$. serpens), in montane forests from c. 1500 to $2000 \mathrm{~m}$ (H. bisetosum), and presumably as 
facultative rheophytes. The occurrence in generally closed undisturbed forests may be due to the fact that their exposed living climbing roots are draught sensitive (Clausing \& Renner 2001a: 57).

Medinilla radicans Blume and $M$. rubrifrons Regalado are also root climbers, but Clausing \& Renner (2001a: t. 3) regarded them as parallel developments in Medinilla.

\section{Vestiture}

The Melastomataceae presents the greatest diversity of vestiture in the angiosperms (Wurdack 1986). Conventionally, trichome characters have been used in species delimitation in the Melastomataceae because of their diversity and constancy (Gleason 1939). However, on young stems or innovations the indument when present may be quite variable in expression and it may change with maturity and also may vary considerably between individuals or populations, yet many species display a remarkable constancy in trichome size, posture, pattern, and distribution. Remarkable is $H$. bisetosa which has both apparently stipitate stellate hairs on the innovations and sessile stellate hairs on the hypanthia, these types being extremely rare for the genus. Terms used in characterising the vestiture are used here in the following sense:

$\begin{array}{ll}\text { hirsute: } & \text { covered with long, rather stiff trichomes. } \\ \text { hirsutulous: } & \text { minutely hirsute. } \\ \text { pilose: } & \text { with soft, shaggy trichomes, they appear shorter } \\ & \text { and sparser than hirsute. } \\ \text { stellate: } & \text { trichomes star-shaped, sessile or stipitate. }\end{array}$

\section{Innovations and branchlets}

With time the innovations increase in diameter and the mature stems or branchlets develop the distinctive lobed woody stele. Young branchlets appear pubescent (hirsute) only in one species (H. barbatum).

The bark of the branchlets is either smooth, roughly striate, or covered by warty elements (here termed pustulate). Branchlets can attain a diameter of at least $15 \mathrm{~mm}$. Yet this may be an artifact, as old and thicker stems perhaps have become leafand flowerless and so are not collected, just as in the youngest innovations where anisophylly might have been observed.

Only one collector mentioned the direction of climbing: sinistrorse for $H$. barbatum from New Guinea (BW 8404 (Vink)). This direction agrees with our observation in a collection from Borneo (S. 12139 (Ashton)) of $H$. decurrens, which suggests that the direction of climbing might be uniform at the generic level.

\section{Petioles}

A generic character seems to be that the leaves are longpetiolate and the contour of the petioles proved to be useful in the distinction of a group of species, where they are narrowly winged: $H$. coronatum, $H$. decurrens, and $H$. flagellatum. Vestiture of the petioles varies between hirsutulous $(H$. barbatum, $H$. coronatum, $H$. flagellatum, $H$. serpens), pilose $(H$. formanii), or generally glabrous.

\section{Leaves}

The Melastomataceae appears to be the largest family of flowering plants characterised by acrodromal or campylodromous pinnate venation (Clausing \& Renner 2001b: 486, 492).

The path followed by the primary nerves from the base of the leaf to the apex is an important qualitative character. Thus leaves can be either campylodromous or basal- or suprabasal acrodromous. Campylodromous nervation (H. cordatum, $H$. serpens) is used here in the sense of Hickey (1973): "several primary veins [nerves] originating at, or close to, a single point and running in strongly developed, recurved arches before converging towards the leaf apex". In contrast, acrodromous nervation differs in the arches which are not recurved at the base. Acrodromous nervation can be further subdivided by the position at which the nerves originate. Thus in basal acrodromous nervation, the acrodromous nerves originate at or very close (a few $\mathrm{mm}$ ) to the base of the blade, while in suprabasal acrodromous nervation, they originate several $\mathrm{cm}$ above the base of the blade $(H$. coronatum and $H$. loratum). This character is indicated here by the distance of the first pair of nerves from the base of the blade. Another character using venation is the distance between the most distal pair of nerves and the preceding pair.

The number of nerves, type of venation, presence of secondary nerves and other characters found in the leaves (see below) are very useful for distinguishing species in Melastomes.

The blades may have a conspicuous submarginal vein (less wide than the secondary nerves) but this can be inconspicuous to apparently absent $(H$. bisetosum, $H$. sandakanense).

The shape of the base of the blade is also important as a vegetative character and the terminology followed here is that as found in Hickey (1973). It is cordate in two species: H. cordatum and $H$. serpens. It is cuneate (margins straight or nearly so, forming a 'basal wedge' of less than $90^{\circ}$ ) in $\mathrm{H}$. barbatum. An acute leaf base (the very base acute, margins curved and not straight) is the most common case $(H$. alternifolium, $H$. bisetosum, $H$. capillipes, $H$. clemensiae, $H$. kemulense, and $H$. sandakanense). Attenuate leaves (in $\mathrm{H}$. formanii) are characterised by the margins progressively converging to the base and slightly extending downward along the petiole. Long-attenuate leaves $(H$. loratum) differ from the previous one in the abrupt arch they form at the point of origin of the first pair of nerves, their margins converging to the leaf base already very high up in the leaf. The leaf base is decurrent when its margin extends downward along the petiole at a low angle to it $(H$. coronatum, $H$. decurrens, $H$. flagellatum).

Secondary venation is generally prominent (except in $\mathrm{H}$. bisetosum). The angle of divergence of the secondaries is measured between the branch and the continuation of the source vein above the point of branching (see Hickey 1973). It is acute $\left(65-80^{\circ}\right)$ in all cases but for $H$. sandakanense where the secondaries diverge at a right angle.

\section{Domatia}

Within Melastomataceae myrmecodomatia are known to occur in c. 10 genera, e.g. Clidemia D.Don, Maieta Aubl., Miconia Ruiz \& Pav., Myrmidone Mart., Tococa Aubl., and Topobea Aubl. (Jacobs 1968, Cabrera \& Jaffe 1994).

Of all the collections studied here only $\mathrm{H}$. barbatum once (out of four) had what appear to be acaridomatia on the leaf underside (BW 8404 (Vink)). They appear as adjacent leaf pouches on each nerve pair and their size is greater in the distalmost pair of nerves than in the proximal ones. In the first proximal pair of nerves domatia appear absent (or if present they must be very much reduced).

Nearly $20 \%$ of the myrmecophytes known worldwide belong to the family Melastomataceae (Benson 1985, Huxley 1986) but it seems ants have never been associated with Heteroblemma and the size of the pouches (a few $\mathrm{mm}^{2}$ ) seems to be too small for them, anyway. As mites are small and soft bodied they are usually lost when plants are pressed and dried and therefore are rarely observed in the domatia of herbarium specimens (Almeda 2001), but in the field in Central America they have been collected in the domatia of Melastomataceae (Almeda 1989, Pemberton \& Turner 1989). 


\section{Inflorescences and pedicels}

Flowers are crowded in dense or lax clusters on the old wood or on leaf axils. They are born singly or rarely in cymes, subtended by lanceolate and glabrous $0.5-2.5 \mathrm{~mm}$ bracts, these at times are papillose. The pedicels are slender and vary in length: in the flowers they range from $5-20 \mathrm{~mm}$. In fruit they are usually longer, from 5-40 mm. In flower and fruit they can be either glabrous or pubescent in various degrees (see vestiture).

\section{Hypanthium and sepals - Fig. 2}

The hypanthium is elliptic or urceolate in unopened buds and during anthesis its rim may become truncate whereby it may become campanulate. Hypanthia are hirsute in $H$. barbatum, $H$. capillipes, and $H$. serpens. Their length is measured from the torus downwards to the attachment to the pedicel. The term 'torus' is used here in the sense of Gleason (1939) for the ring of vascular tissue at the apex of the hypanthium upon which the petals and stamen are inserted. The sepals can vary from $0.5-2 \mathrm{~mm}$ in length and in several species they are minutely to conspicuously tooth-shaped. Teeth are broadly triangular to ovate, those less than $0.5 \mathrm{~mm}$ were considered to be 'minute'; those longer than $0.5 \mathrm{~mm}$ were called 'conspicuous'. The teeth are mostly glabrous but in certain species they can be hirsute ( $H$. capillipes) or prolonged by the presence of a slender 1-3 $\mathrm{mm}$ long hair $(H$. barbatum, $H$. coronatum, $H$. serpens).

\section{Petals}

Petals upon expansion are orientated in a spreading whorl. In Heteroblemma as in most Melastomataceae they are fugacious. Their number (4) and shape is constant: they are ovate, acute, and with a clawed base. Outside they are generally covered by minute reddish (i.s.) papillae which can be best observed after simmering the flowers. Notes on petal colour have not been recorded for all species (they are missing in $H$. capillipes, $H$. clemensiae, $H$. coronatum, $H$. kemulense, $H$. sandakanense). When present, they are usually noted as white or various shades of pink (whitish pinkish, pale red), or purple. Extremely rare for this alliance is the report of yellow in $H$. decurrens by the collectors (S. 22818, Jugah ak. Kudi and Chew Wee-Lek 346), for Catanthera royenii M.P.Nayar (Van Royen \& Sleumer 7405), and for Phyllapophysis schlechteri Mansf. (Kalkman s.n.).

\section{Androecium}

In bud the anthers lie in extra-ovarian pockets, their dorsal sides facing in towards the ovary and their ventral sides facing out. When the flower opens, the anthers are pulled from the pockets, become more or less erect and slightly twist into a row at the lower region of the flower. The style curves upwards and the stigma is positioned above this row. See Fig. 2. Anthesis is here used in the sense of Wurdack (1953: 352) as the time at which this erection occurs. At anthesis their position changes from the being inflexed in bud to erect.

Filaments are taxonomically trivial, they are equal or slightly unequal, ligular, broader at the their base than at the apex, dorsoventrally flattened, striate, and glabrous, the basal margins are only slightly expanded. Their length varies from $1.5-3.5 \mathrm{~mm}$.

Because in the drying and mounting process petals and anthers are often lost in the Melastomataceae they are unknown for $H$. capillipes, $H$. clemensiae, $H$. coronatum, $H$. kemulense, and $H$. sandakanense. It may be deduced from the other species that they, too, are diplostemonous, isomorphic, glabrous, taper from the bases of the thecae to the single apical pore, and present a slightly to well-developed connective that appears in the form of two slightly elevated ridges. From the number of the calyx teeth, extra-ovarian pockets, and the number of ovary locules it is inferred that they are also 4-merous.

The dorsal spur of the anthers, where known, is conspicuous and usually lanceolate but the lateral appendages that protrude to the sides are usually straight and minute, usually less than $0.5 \mathrm{~mm}$, but reaching $1 \mathrm{~mm}$ in $H$. barbatum, $H$. bisetosum, and H. serpens.
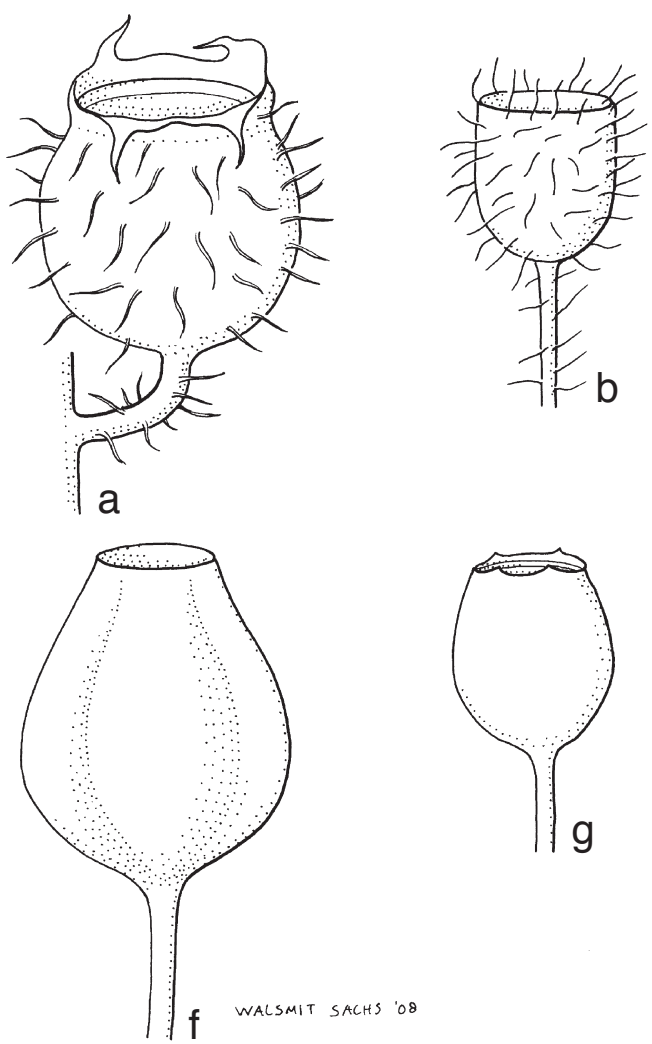
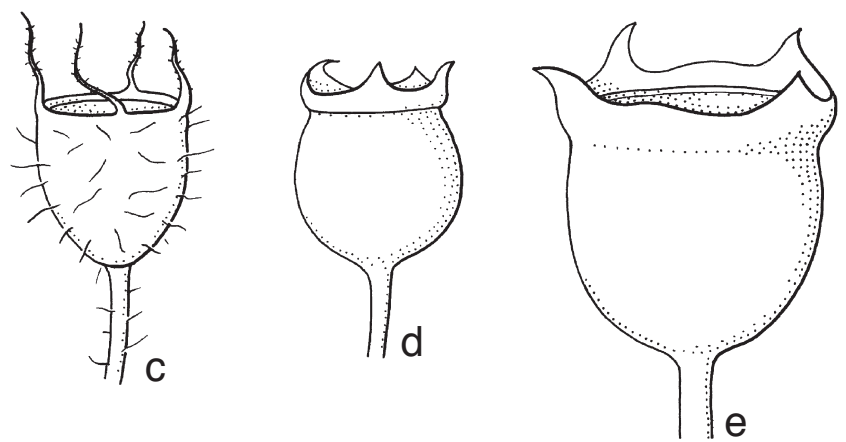
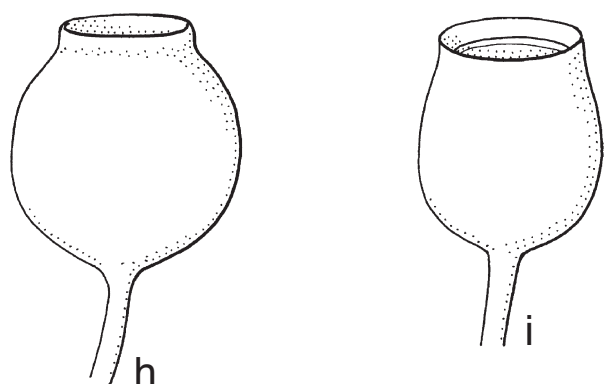

Fig. 2 Examples of some hypanthia. a. Heteroblemma barbatum (BW 8404 (Vink)); b. H. capillipes (S. 36279 (Ilias Paie)); c. H. serpens (Ridley July 1893); d. H. coronatum (SAR 25080 (Banyeng ak Nudong)); e. H. clemensiae (Clemens 3829); f. H. kemulense (Endert 4330); g. H. loratum (Haviland 1682); h. H. flagellatum (Haviland 68); i. Heteroblemma alternifolium (Soedarsono 378). - Scale bar $=1 \mathrm{~mm}$. 
The exception seems to be that in $H$. barbatum the dorsal spur is rectangular and the lateral appendages are recurved.

Pollination is likely by insects like bees and bumblebees, hoverflies, and the like. The position of the anthers and the apical pores suggest pollination by 'buzzing', as is well-known from the flowers of e.g. Solanum. For this they have to alight on the flower.

\section{Gynoecium}

The ovary is 4-locular, concrescent with the hypanthium, and with 8 extra-ovarian chambers. In Medinilla the depth of these does not reach beyond the middle of the ovary, in contrast in Heteroblemma they reach nearly to the base.

The style in bud ranges from $5-8 \mathrm{~mm}$, its colour is white, pink, or reddish purple. Generally, it is covered by minute reddish (i.s.) papils from the base upwards. At anthesis it is usually exserted and continues to increase in length even after the corolla drops. The stigma is always punctiform, and only for two species the colour has been recorded: white.

\section{Fruit}

In the palaeotropical Dissochaeteae there has been an independent evolution of berries from capsules (Clausing \& Renner 2001b). Fruits in Heteroblemma are hard berries (sclerified pericarp) with persistent placentas, their inside is usually filled with jelly. Catanthera has soft berries with a weakly sclerified pericarp, while in Kendrickia in contrast has a fleshy capsule that opens by four longitudinal cracks (Clausing \& Renner 2001a). Generally, the surface is smooth, rarely rugose-wrinkled (H. kemulense) and occasionally it appears ribbed $(H$. barbatum) and with thicker walls. Seeds are numerous, commashaped with a papillate testa, up to $1 \mathrm{~mm}$ long, bright yellow to orange.

The way of dispersal is unknown, but at least in the instances where jelly was observed in the fruits it is likely to be by birds. Clausing et al. (2000) mentioned the presence of 'woody berries', 'fleshy capsules', which are terms in contradiction, for the fruits here are not berries (fleshy, indehiscent, mesocarp well-developed, the seeds immersed in it, no cavities present, no developed septs), nor capsules (dry, dehiscent, severalseeded, pericarp splitting open, the valves remaining attached). Curiously, although this seems to be a fairly common type of fruit in the tropics, there is no general term.

\section{Distribution}

Most of the species are Malesian with a centre of diversity in Borneo (11 species, 8 endemic), followed by Vietnam ( 3,1 endemic), Sumatra (3), Peninsular Malaysia (2), Celebes (1) and the island of New Guinea (1 endemic).

Of the Borneo endemics, five (so far) are exclusive to Sabah and Sarawak ( $H$. capillipes, $H$. coronatum, H. flagellatum, H. loratum, $H$. sandakanense) and three are restricted to Kalimantan ( $H$. cordatum, $H$. formanii, $H$. kemulense).

The most widespread species (and also the best collected one) is $H$. alternifolium distributed from Vietnam, the Malaysian Peninsula (but so far not in between), Sumatra, Borneo, and Celebes. In Vietnam Averyanov et al. (2003) stated that $H$. alternifolium is very common in closed evergreen tropical monsoon submontane broadleaved forests between 600-1400 $\mathrm{m}$ and also in riparian communities between 600-1000 m. The collections made by Averyanov et al. in 2001-2002 have not been studied but we believe they may belong to any of the three species found in Vietnam $(H$. alternifolium, $H$. bisetosum, or H. clemensiae).

Five species are represented by only one collection ( $H$. clemensiae, $H$. cordatum, $H$. coronatum, $H$. kemulense, $H$. sandakan- ense). Of the 9 remaining species all but one $(H$. alternifolium: 107 collections) have less than 15 collections $(H$. decurrens 13 ; $H$. loratum $11 ; H$. serpens $11 ; H$. capillipes $7 ; H$. formanii $7 ; H$. bisetosum $5 ; H$. flagellatum $5 ; H$. barbatum 4$)$.

\section{KEY TO THE SPECIES}

1. Mature leaf blades underneath pubescent $\ldots \ldots \ldots 2$

1. Mature leaf blades underneath glabrous . . . . . . 7

2. Leaf blades base cordate, primary venation 9-plinerved, campylodromous, distalmost primaries $5 \mathrm{~mm}$ away from the preceding pair. Hypanthium $3 \mathrm{~mm}$ long. . . . . . . . . 3

2. Leaf blades base cuneate, attenuate or decurrent, primary venation 3-7-plinerved, basal or suprabasal acrodromous, distalmost primaries $10-65 \mathrm{~mm}$ away from the preceding pair. Hypanthium $3.5-4 \mathrm{~mm}$ long . . . . . . . . . . 4

3. Innovations and leaf blades underneath hirsutulous. Petioles and pedicels glabrous. Hypanthium glabrous, teeth minute or absent, $0-0.2 \mathrm{~mm}$ long, glabrous. Anthers lateral appendages $0.2 \mathrm{~mm}$ long. Fruit glabrous, calyx remnants inconspicuous or absent in fruit, pedicels in fruit glabrous. .

6. H. cordatum

3. Innovations, leaf blades underneath, pedicels, hypanthium hirsute. Petioles hirsutulous. Hypanthium teeth conspicuous, 0.5-1 mm long, crowned with a slender hair. Anthers lateral appendages $0.5 \mathrm{~mm}$ long. Fruit glabrescent, calyx remnants conspicuous in fruit, pedicels in fruit glabrescent . . . . . . .

14. H. serpens

4. Innovations glabrous. Petioles winged. Leaf blades base decurrent. Calyx teeth $0.25-1 \mathrm{~mm}$ long $\ldots \ldots \ldots \ldots 5$

4. Innovations hirsute or hirsutulous. Petioles terete. Leaf blades base cuneate or attenuate. Calyx teeth $0-1.5 \mathrm{~mm}$ long $\ldots \ldots \ldots \ldots \ldots \ldots \ldots \ldots \ldots \ldots \ldots \ldots \ldots \ldots$

5. Leaf blades linear-lanceolate, 5-6 cm wide, 5-6 times as long as wide, margin entire, underneath hirsutulous, primary venation 3-plinerved, first pair of primaries $50 \mathrm{~mm}$ away from the leaf base. Calyx teeth conspicuous, $1 \mathrm{~mm}$ long. Fruit 5-6 by $5 \mathrm{~mm}$, calyx remnants conspicuous in fruit. . . . . . .

7. H. coronatum

5. Leaf blades elliptic or oblong, $11.5-16.5 \mathrm{~cm}$ wide, $1.7-2.1$ times as long as wide, margin laxly serrulate, underneath hirsute, primary venation 7-plinerved, first pair of primary nerves 5-15 $\mathrm{mm}$ away from the base. Calyx teeth minute, $0.2 \mathrm{~mm}$ long. Fruit $7-8$ by $7-8 \mathrm{~mm}$, calyx remnants inconspicuous or absent in fruit . . . . . . . 9. H. flagellatum

6. Innovations hirsute, branchlets smooth. Petioles $3-6 \mathrm{~mm}$ wide, hirsutulous. Leaf blades $27.5-42.5 \mathrm{~cm}$ long, base cuneate, margin glabrous, underneath hirsutulous, distalmost primaries $35-65 \mathrm{~mm}$ away from the preceding pair. Bracts $2.5 \mathrm{~mm}$ long. Pedicels of the flowers $5 \mathrm{~mm}$ long, hirsute. Hypanthium hirsute, teeth conspicuous, $1.5 \mathrm{~mm}$ long, crowned with a slender hair. Anthers lateral appendages recurved, $1 \mathrm{~mm}$ long, dorsal spur rectangular. Fruit $9-10$ by $8-9 \mathrm{~mm}$, hirsute, calyx remnants conspicuous in fruit, pedicels in fruit $5 \mathrm{~mm}$ long, hirsute. - New Guinea. . . . . 2. H. barbatum 6. Innovations hirsutulous. Branchlets striate. Petioles $2 \mathrm{~mm}$ wide, pilose. Leaf blades $13.5-23.5 \mathrm{~cm}$ long, base attenuate, margin ciliolate, underneath pilose, distalmost primaries 10-30 $\mathrm{mm}$ away from the preceding pair. Bracts $1-1.5$ $\mathrm{mm}$ long. Pedicels of the flowers $10-20 \mathrm{~mm}$ long, pilose or glabrous. Hypanthium pilose or glabrous, teeth absent. Anthers lateral appendages not recurved, 0.2-0.4 mm long, dorsal spur triangular-lanceolate. Fruit $5-7$ by $5-6.5 \mathrm{~mm}$, glabrous, calyx remnants inconspicuous or absent in fruit, pedicels in fruit $15-30 \mathrm{~mm}$ long, glabrous. - Borneo ...

10. H. formanii 
7. Leaf blades base long-attenuate or decurrent. . . . . . 8

7. Leaf blades base acute . . . . . . . . . . . . . . 9

8. Innovations glabrescent. Petioles winged. Leaf blades 9-17 $\mathrm{cm}$ wide, 2-3.4 times as long as wide, 1.5-2.8 times as long as the petiole, base decurrent, margin laxly serrulate, ciliolate, apex acuminate, primary venation 5-7-plinerved, basal acrodromous, first pair of primaries 5-15 mm away from the leaf base, tertiary nerves conspicuous. Calyx teeth absent. Anthers lateral appendages $0.2 \mathrm{~mm}$ long. Calyx remnants inconspicuous or absent in fruit $8 . H$. decurrens

8. Innovations hirsutulous. Petioles terete. Leaf blades $3.5-6.5 \mathrm{~cm}$ wide, $4.6-6.6$ times as long as wide, 3-5.6 times as long as the petiole, base long-attenuate, margin entire, glabrous, apex acute, primary venation 3-plinerved, suprabasal acrodromous, first pair of primaries 35-110 $\mathrm{mm}$ away from the leaf base, tertiary nerves faintly visible or inconspicuous. Calyx teeth minute, $0.2-0.4 \mathrm{~mm}$ long. Anthers lateral appendages $0.3 \mathrm{~mm}$ long. Calyx remnants conspicuous in fruit . . . . . . . . . . 12. H. loratum

9. Submarginal vein inconspicuous, tertiary nerves faintly visible or inconspicuous. . . . . . . . . . . 10

9. Submarginal vein conspicuous, tertiary nerves conspicuous....................... 11

10. Innovations hirsute with stellate hairs. Branchlets striate. Petioles $3.5-6.5 \mathrm{~cm}$ long, 1-1.5 mm wide. Leaf blades 8-14 cm long, 1.9-2.6 times as long as wide, secondary nerves inconspicuous. Pedicels of the flowers with sessile stellate hairs. Hypanthium with sessile stellate hairs. Fruit $7 \mathrm{~mm}$ long, pedicels in fruit $15 \mathrm{~mm}$ long 3. H. bisetosum

10. Innovations glabrous. Branchlets pustulate. Petioles 7-12.5 $\mathrm{cm}$ long, 3-5 mm wide. Leaf blades $23.5-26.5 \mathrm{~cm}$ long, 2.9-3.8 times as long as wide, secondary nerves conspicuous. Pedicels of the flowers glabrous. Hypanthium glabrous. Fruit $6 \mathrm{~mm}$ long, pedicels in fruit $25-30 \mathrm{~mm}$ long 13. H. sandakanense

11. Innovations either hirsute, glabrescent or glabrous. Leaf blades apex acuminate. Fruit glabrous, pedicels in fruit glabrous. . . . . . . . . . . . . . . 12

11. Innovations hirsutulous. Leaf blades apex acute. Fruit hirsute, pedicels in fruit hirsutulous .... 4. H. capillipes

12. Innovations glabrescent or glabrous. Primary venation 5-9plinerved. Calyx remnants inconspicuous or absent in fruit ................... 13

12. Innovations hirsute, primary venation 7-plinerved. Calyx remnants conspicuous in fruit ..... 5. H. clemensiae

13. Fruit arising in fascicles from old wood or leaf axils, 7-9 by $6-7 \mathrm{~mm}$, smooth. Innovations glabrescent, branchlets pustulate or striate . . . . . . . . 1. H. alternifolium

13. Fruit arising singly from leaf axils, c. 11 by $10 \mathrm{~mm}$, rugose or slightly ribbed. Innovations glabrous, branchlets smooth 11. H. kemulense

1. Heteroblemma alternifolium (Blume) Cámara-Leret, Ridd.Num. \& Veldk., comb. nov. — Fig. 1, 2I

Medinilla alternifolia Blume, Mus. Bot. 1 (1849) 19. — Lectotype: Korthals s.n. 'Indrapura' (holo L, sh. no. 908.129-1597), partly designated by Bakhuizen van den Brink Jr (1943, 1946, 1947: 177, 'Blume s.n.'), sheet number selected here.

Medinilla scandens King (1900) 60. — Lectotype: King's Collector 1814 (holo $\mathrm{CAL} ; \mathrm{BM})$, designated here.

Innovations glabrescent. Branchlets striate to pustulate, glabrous. Petioles terete, $3.5-29 \mathrm{~cm}$ by $2-5 \mathrm{~mm}$, glabrous (rarely pilose). Leaves elliptic to lanceolate, $9-32$ by $6-16.5 \mathrm{~cm}, 1.1-4$ times as long as wide, 1-4 times as long as the petioles, base acute, margin entire or laxly serrulate, glabrous or ciliolate, apex acuminate, pergamentaceous (i.s.), underneath glabrous, 5-9-plinerved, basal acrodromous, first pair of primaries 2-10 $\mathrm{mm}$ away from the base, distalmost primaries $1-100 \mathrm{~mm}$ away from the preceding pair, submarginal vein conspicuous, secondary nerves conspicuous, angle of divergence from midvein acute wide, tertiary nerves conspicuous. Bracts 1-2 mm long. Flowers born on fascicles on old wood, pedicels 5-20 $\mathrm{mm}$ long, glabrous (rarely pilose). Mature floral buds $8-10$ by 3-4 $\mathrm{mm}$. Hypanthium urceolate to campanulate, 3-4 $\mathrm{mm}$ long, glabrous (rarely pilose). Sepals $0.5-1.5 \mathrm{~mm}$ long, teeth absent or minute, $0-0.5 \mathrm{~mm}$, apex glabrous. Petals $5-6 \mathrm{~mm}$ long, white, pink, or violet, outside finely papillose. Filaments 1.5-3 mm long. Anthers $4-5 \mathrm{~mm}$ long, lateral appendages not recurved, $0.25-0.4(-2) \mathrm{mm}$ long, dorsal spur triangular to lanceolate, $1-1.5 \mathrm{~mm}$ long. Style 5-7 mm long, glabrous to papillose. Fruit $7-9$ by $6-7 \mathrm{~mm}$, glabrous (rarely pilose), calyx teeth inconspicuous or absent; pedicels in fruit 5-30 mm long, glabrous (rarely hirsutulous); inside filled with jelly.

Distribution — Vietnam (Thua Thiên-Huê), Peninsular Malaysia (Johor, Pahang, Perak, Terengganu), Sumatra (widespread), Borneo (widespread), Celebes (Upper Sopu Valley).

Habitat - Primary mixed dipterocarp forest, secondary forest, marshy forest, fresh water swamp forest, near water, along river side, on sandy clay, loam, sandstone, sometimes ultramafic, $0-1100 \mathrm{~m}$ altitude.

Collector's notes - Succulent twining climber with roots, becoming lianaceous, vine, up to $15 \mathrm{~m}$ high. Innovations purplish, bronze. Stems, twigs grey brown, brownish, leaves apparently on short shoots, growth in length apparently by other stems with more distant leaves (Stevens et al. 521). Young leaves opposite, very anisophyllous, older ones apparently alternate. Petioles thick-fleshy-juicy, pale green, purplish reddish. Leaves mid-green above, beneath reddish purple becoming pale green, deeply ribbed, nerves reddish, bullate between the nerves. Inflorescences cauliflorous, deep pinkish red. Peduncles green, red. Pedicels yellowish green. Hypanthium pink, red, reddish green, yellowish green. Petals white, pinkish (especially at the tips), pink lilac, violet. Filaments white, anthers creamy yellow, yellow, appendage undulately margined. Styles white. Stigma yellowish, bright red. Fruits berries, dirty pale greenish, yellowish green, pale yellow, yellow, lemon yellow, greenish orange, orange, reddish orange, bright red.

Notes - The best collected species of the genus, it presents great variability in the morphology of the leaves and the reported colour of the fruits, whereby the 'fruits' clearly are hypanthia from which the petals and stamens had dropped off.

From Celebes there is only one collection (Van Balgooy 3531) and it has hirsutulous pedicels but otherwise it falls within the variability of the species. From Vietnam there is only one collection (Poilane 29857) found in the Thua Thiên-Huê area, with the longest lateral appendages of all $\mathrm{H}$. alternifolium collections (up to $2 \mathrm{~mm}$ ).

It differs from $H$. cordatum in the leaf with an acute base, basal acrodromous venation, and the glabrous underside.

107 collections were seen.

2. Heteroblemma barbatum (Bakh.f.) Cámara-Leret, Ridd.Num. \& Veldk., comb. nov. - Fig. 2a

Medinilla barbata Bakh.f., Contr. Melastom. (1943) 176. इ Recueil Trav. Bot. Néerl. 40 (1946) 176. इ Meded. Bot. Mus. Herb. Rijks Univ. Utrecht 91 (1947) 176. - Type: Lam 663 (holo L; BO) .

Medinilla jappenensis Ohwi, ined. — Voucher: Aet \& Idjan 825 (BO, L).

Innovations hirsute (setae up to $5 \mathrm{~mm}$ long). Branchlets smooth, hirsute (setae up to $8 \mathrm{~mm}$ long). Petioles terete, $5-14.5$ by $3-6$ $\mathrm{mm}$, hirsutulous. Leaves oblong to lanceolate, $27.5-42.5$ by $6.5-13 \mathrm{~cm}, 2.8-3.9$ times as long as wide, $2.2-3.5$ times as 
long as the petioles, base cuneate, margin entire, glabrous, apex shortly acuminate, texture pergamentaceous (i.s.), underneath hirsutulous (especially on the primaries), 5-7-plinerved, basal acrodromous, first pair of primaries $3 \mathrm{~mm}$ away from base, distalmost primaries $35-65 \mathrm{~mm}$ away from the preceding pair, submarginal vein conspicuous, secondary nerves conspicuous, 30-35 pairs, angle of divergence from midvein acute wide, tertiary nerves conspicuous. Bracts $2.5 \mathrm{~mm}$ long. Pedicels $5 \mathrm{~mm}$ long, hirsute. Mature floral buds urceolate to campanulate, $8 \mathrm{~mm}$ long. Hypanthium urceolate to campanulate, $3.5 \mathrm{~mm}$ long, yellowish brown, hirsute, hairs up to $5 \mathrm{~mm}$ long. Sepals $0.5 \mathrm{~mm}$ long, teeth conspicuous, $1.5 \mathrm{~mm}$ long, crowned by a $2 \mathrm{~mm}$ long hair. Petals $5 \mathrm{~mm}$ long, pink, outside papillose. Filaments 2-3 mm long. Anthers $3 \mathrm{~mm}$ long, lateral appendages recurved, $1 \mathrm{~mm}$ long, dorsal spur rectangular, $1 \mathrm{~mm}$ long. Fruit $9-10$ by $8-9 \mathrm{~mm}$, light green when young, later on white, surface ribbed, hirsute, calyx teeth persistent; pedicels in fruit $5 \mathrm{~mm}$ long, hirsute; inside filled with jelly, seeds less than 0.5 $\mathrm{mm}$ long, yellow (i.s.).

Distribution — Irian Jaya (Biak, Jayapura (Hollandia)), Jappen Biak, Mamberamo), Papua New Guinea (W Prov.).

Habitat - Mixed rain forest, soil peaty, clay with gravel, 60$850 \mathrm{~m}$ altitude.

Collector's notes - Sinistrorse root climber. Hypanthium yellowish brown. Petals pink. Fruit pale green when young, later white.

Notes - BW 8404 (Vink) is the only collection out of a total of four which has what apparently are acaridomatia on its leaves. These small pouches are a few $\mathrm{mm}^{2}$ in area and are located adjacent to the midvein.

4 collections were seen.

3. Heteroblemma bisetosum (Bakh.f.) Cámara-Leret, Ridd.Num. \& Veldk., comb. nov.

Medinilla bisetosa Bakh.f., Contr. Melastom. (1943) 177. इ Recueil Trav. Bot. Néerl. 40 (1946) 177. इ Meded. Bot. Mus. Herb. Rijks Univ. Utrecht 91 (1947) 177. - Type: Forbes 2342 (holo L; BM, BO).

Medinilla alternifolia auct. non Blume: Baker, J. Bot. 62, Suppl. 1 (1924) 40.

Innovations hirsute, hairs stipitate stellate. Branchlets striate, glabrous. Petioles terete, $3.5-6.5 \mathrm{~cm}$ by $1-1.5 \mathrm{~mm}$, glabrous. Leaves elliptic to oblong, 8-14 by $4-7 \mathrm{~cm}, 1.9-2.6$ times as long as wide, 1.7-2.8 times as long as the petioles, base acute, margin entire, glabrous, apex acuminate, texture somewhat leathery, thin (i.s.), underneath glabrous, 5-plinerved, basal acrodromous, first pair of primaries $1-5 \mathrm{~mm}$ away from the base, distalmost primaries $5-20 \mathrm{~mm}$ away from the preceding pair, submarginal vein inconspicuous, secondary nerves inconspicuous. Bracts $1 \mathrm{~mm}$ long. Flowers born in dense fascicles on old branchlets, pedicels $5 \mathrm{~mm}$ long, with sessile stellate hairs or glabrous. Hypanthium urceolate to campanulate, $3 \mathrm{~mm}$ long, with sessile stellate hairs to glabrous. Sepals $1 \mathrm{~mm}$ long, teeth minute, less than $0.5 \mathrm{~mm}$, glabrous. Petals pink. Filaments $2 \mathrm{~mm}$ long. Anthers 3-4 mm, lateral appendages not recurved, $0.5-1 \mathrm{~mm}$ long, dorsal spur triangular, $0.5-1.5 \mathrm{~mm}$ long. Fruit 7 by $5 \mathrm{~mm}$, surface smooth, glabrous, calyx teeth absent; pedicels in fruit $15 \mathrm{~mm}$, glabrous; inside filled with jelly, seeds greater than $0.5 \mathrm{~mm}$ but less than $1 \mathrm{~mm}$, yellow (i.s.).

Distribution - Sumatra (W coast) and Vietnam (Lao Cai, Lam Dong, Ninh Thuan and Kontum provinces).

Habitat - Notes on habitat and ecology are only available from Vietnam collections. In closed primary broadleaved mountain forest, between 1500-2000 m, common.

Collector's notes - Epiphytic creeping vine up to $15 \mathrm{~m}$ long, cauliflorous. Petals pale pink to pink.

Notes - Bakhuizen van den Brink Jr erroneously cited Bünnemeijer 5662 as the type. This is the type of M. buennemeijeri
Bakh.f. (1943, 1946, 1947: 192). The Forbes collection is correctly cited in his list of collectors and the specimen itself in $L$ is also so labelled by Bakhuizen van den Brink Jr himself. This mix-up of type citations is not covered by the Code, but we have regarded it as a bibliographic error that can be corrected, similar to Art. 33.5. In 1943 one was not required to designate a type, anyway (Art. 8).

Inexplicable is the disjunct distribution between Vietnam and Sumatra. Previously only known from the type in Sumatra, it has also been found in Vietnam. Although we tried, the material is indistinguishable except for the stipitate stellate hairs on the innovations and the sessile and stellate hairs in the younger flower pedicels and buds, unique for Heteroblemma.

5 collections were seen.

4. Heteroblemma capillipes (Regalado) Cámara-Leret, Ridd.Num. \& Veldk., comb. nov. - Fig. 2b

Medinilla capillipes Regalado, Blumea 35 (1990) 61, t. 14. — Type: S. 36279 (Ilias Paie) (holo K; KEP, L, MO, SAN, SAR).

Innovations hirsutulous. Branchlets glabrous. Petioles terete, $6.5-13 \mathrm{~cm}$ by $2-3 \mathrm{~mm}$, glabrous or setose (red). Leaves elliptic to oblong, $14-24$ by $6.5-11.5 \mathrm{~cm}, 1.6-2.8$ times as long as wide, $1.5-2.4(-3.5)$ times as long as the petioles, base acute, margin entire, ciliolate, apex acute, pergamentaceous (i.s.), underneath glabrous, 5-plinerved, basal acrodromous, first pair of primaries $2 \mathrm{~mm}$ away from the base, distalmost primaries $5 \mathrm{~mm}$ away from the preceding pair, submarginal vein conspicuous, secondary nerves conspicuous, 20-25 pairs, angle of divergence from midvein acute wide, tertiary nerves conspicuous. Bracts 1.5-2 mm long. Flowers born on old wood or axillary on young stems, pedicels $15-20 \mathrm{~mm}$ long, hirsutulous. Hypanthium urceolate to campanulate, 3-4 mm long, hirsute, hairs yellowish. Sepals $0.5 \mathrm{~mm}$ long, teeth minute, less than $0.5 \mathrm{~mm}$ long, hirsute. Petals pale pink. Fruit $6-8$ by $5-7 \mathrm{~mm}$, bright yellow, orange or reddish orange, smooth, hirsute (rarely glabrescent), hairs brown, calyx teeth persistent; pedicels in fruit 25-40 mm long, green, hirsutulous; inside filled with jelly, seeds less than $0.5 \mathrm{~mm}$ long, yellow orange (i.s.).

Distribution - Endemic of Sarawak (3rd, 7th, and 9th Div.).

Habitat - Along stream banks in forests on yellow sandy soil, on mossy boulders, in seasonally flooded riverine forest on pale yellow clay, as a rheophyte in lowland dipterocarp forest, and on submontane mossy forest, 60-820 m altitude.

Collector's notes - Creeper, climber, or rheophyte, or terrestrial, with adventive roots, up to $2.1 \mathrm{~m}$. Stem dark brown, brown hairy. Leaves slightly papery, above green, beneath pale green. Peduncle dark red. Pedicels pale green. Young calyx pink with long straw-coloured hairs. Petals pale pink. Fruit bright yellow, orange yellow to orange, red, with yellowish orange to brown bristles, pedicel green to yellowish green.

Notes - S. 37559 (Chai et al.) differs in its shorter petioles, leaves being linear-lanceolate, decurrent base, 3-plinerved, but shows the distinctive hirsute fruits.

We are unsure of S. 66556 (Yahud Hj Wat et al.) from the 5th Div. of Sarawak. It differs in its lanceolate to linear-lanceolate leaves, its decurrent base, venation which is 3-plinerved and its glabrous fruits.

7 collections were seen.

5. Heteroblemma clemensiae Cámara-Leret, sp. nov. — Fig. $2 \mathrm{e}$

Innovationes hirsutae, folii lamina basi acuta, apice acuminato, 7-plinervata infra glabra, vena submarginali conspicua, nervis tertiariis conspicuis, fructus glabri, pedicellis glabris, calycis reliquiae conspicuae. - Type: Clemens 3829 (holo K; L, not found). 

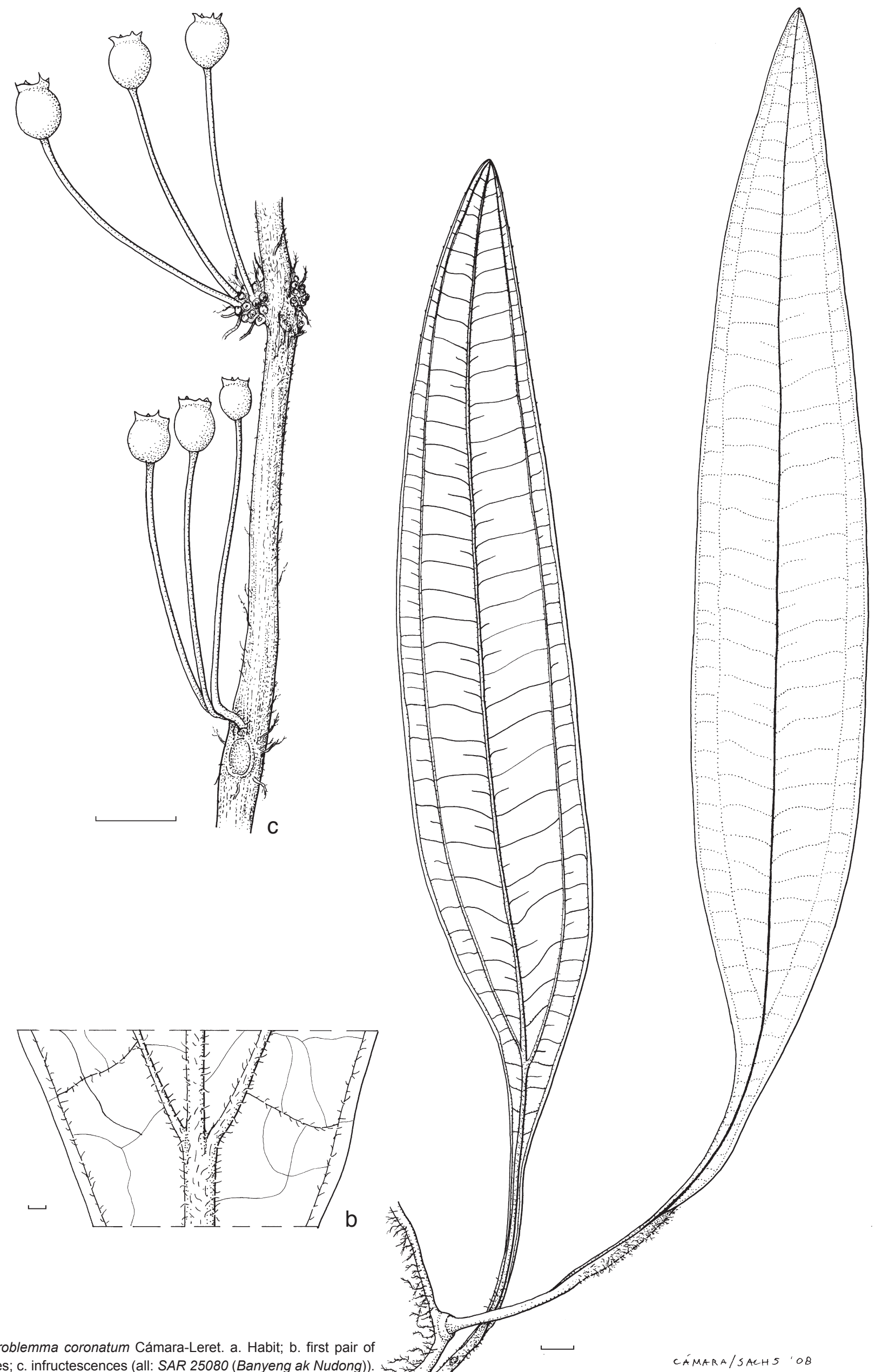

Fig. 3 Heteroblemma coronatum Cámara-Leret. a. Habit; b. first pair of primary nerves; c. infructescences (all: SAR 25080 (Banyeng ak Nudong)). - Scale bars: $a, c=1 \mathrm{~cm} ; \mathrm{b}=1 \mathrm{~mm}$. 
Innovations hirsute. Branchlets striate, glabrous. Petioles terete, $1-6.5 \mathrm{~cm}$ by $3 \mathrm{~mm}$, glabrous. Leaves oblong to lanceolate, $13-23$ by $5-7 \mathrm{~cm}, 2.5-3.3$ times as long as wide, $3.5-15$ times as long as the petioles, base acute to obtuse, margin entire, glabrous, apex acuminate, pergamentaceous (i.s.), underneath glabrous, 7-plinerved, basal acrodromous, first pair of primaries 3-5 $\mathrm{mm}$ away from the base, distalmost primaries $4-5.5 \mathrm{~cm}$ away from the preceding pair, submarginal vein conspicuous, secondary nerves conspicuous, 15-20 pairs, angle of divergence acute wide, tertiary nerves conspicuous. Bracts $2 \mathrm{~mm}$ long. Pedicels up to $20 \mathrm{~cm}$ long, glabrous. Flowers born in dense fascicles on old wood. Buds c. 12 by $7 \mathrm{~mm}$. Hypanthium campanulate, c. 8 by $7 \mathrm{~mm}$, very finely red-papillose. Petals c. 5 by $5 \mathrm{~mm}$, red-purple (i.s.). Filaments c. $2 \mathrm{~mm}$ long; anther c. $1.2 \mathrm{~mm}$ long, dorsal spur adaxially directed, c. $0.5 \mathrm{~mm}$ long, lateral appendages triangular, c. $1 \mathrm{~mm}$ long. Style c. $7 \mathrm{~mm}$ long, white papillose in lower part. Fruits $8.5-10$ by $7-9 \mathrm{~mm}$, smooth, glabrous, calyx teeth persistent, c. $2 \mathrm{~mm}$ long; seeds less than $0.5 \mathrm{~mm}$, yellow (i.s.).

Distribution - Endemic of Vietnam, Tourane (now Da Nang). Habitat - On large forest tree.

Collector's notes - Liana. Flowers in fascicles cauline, near the ground.

Note - Only known from the type. The specimen with flowers in L used by JRN for her 1977 description could not be found again.

\section{Heteroblemma cordatum Cámara-Leret, sp. nov.}

Innovationes hirsutullae, petioli glabri, folii lamina basi cordata infra hirsutulla 9-plinerva nervatione campylodroma nervis primariis a pare precedenti $5 \mathrm{~mm}$ distanti, pedicelli glabri, hypanthium $3 \mathrm{~mm}$ longum glabrum dentibus nullis vel minutis $0-0.2 \mathrm{~mm}$ longis glabris, antherae appendices laterales $0.2 \mathrm{~mm}$ longae, fructus glabri calycis reliquiae nullae vel inconspicuae pedicellis glabris. - Type: Burley, Tukirin et al. 3155 (holo L; A, BO).

Innovations hirsutulous. Branchlets pustulate, glabrous, c. 10$15 \mathrm{~mm}$ diam. Petioles terete, c. $16 \mathrm{~cm}$ by $3-4 \mathrm{~mm}$ wide, glabrous. Leaves $15.5 \mathrm{~cm}$ wide, base cordate, margin laxly serrulate, ciliolate, pergamentaceous, underneath hirsutulous along reticulations, 9-plinerved, campylodromous, first pair of primaries $0-5 \mathrm{~mm}$ away from base, distalmost primaries $5 \mathrm{~mm}$ away from the preceding pair, submarginal vein conspicuous, secondary nerves conspicuous, angle of divergence acute wide, tertiary nerves conspicuous. Bracts $2 \mathrm{~mm}$ long. Flowers born on dense fascicles on old wood, pedicels $10 \mathrm{~mm}$ long, glabrous. Mature floral buds $7-8$ by $3.5 \mathrm{~mm}$. Hypanthium urceolate to campanulate, $3 \mathrm{~mm}$ long, glabrous. Sepals $0.5-1$ $\mathrm{mm}$ long, teeth absent or minute, $0-0.25 \mathrm{~mm}$ long, glabrous. Petals 6-7 mm long, white, outside papillose. Filaments $2 \mathrm{~mm}$ long. Anthers $5 \mathrm{~mm}$ long, lateral appendages not recurved, 0.25 $\mathrm{mm}$ long, dorsal spur triangular to lanceolate. Style $6 \mathrm{~mm}$ long. Fruit 6 by $5 \mathrm{~mm}$, smooth, glabrous, calyx teeth inconspicuous or absent; pedicels in fruit 15-35 mm long, glabrous; seeds less than $0.5 \mathrm{~mm}$, yellow (i.s.).

Distribution - Endemic of W Kalimantan: NE of Pontianak, G. Bentuang area.

Habitat - Mixed dipterocarp forest on sandstone ridge, occasional, $400 \mathrm{~m}$ altitude.

Collector's notes - Climber, $25 \mathrm{~m}$ tall. Petals white.

Notes - Although similar to $H$. serpens by its cordate leaf base and the 9 primary nerves, it is different in its glabrous flower and fruit pedicels and hypanthium, while its calyx teeth are minute or absent and glabrous. It differs from $H$. alternifolium in its cordate leaf base and campylodromous venation and abaxially it is hirsutulous along the reticulations below.

Only known from the type.
7. Heteroblemma coronatum Cámara-Leret, sp. nov. - Fig. $2 b, 3$

Innovationes glabrae, petioli alati, folii lamina linearilanceolata $5-6 \mathrm{~cm}$ lata 5-6-plo longa quam lata basi decurrenti infra hirsutulla 3-plinerva venatione suprabasaliter acrodroma nervorum parimariorum pare prima $50 \mathrm{~mm}$ laminae basi distanti, hypanthium 3.5-4 mm longum dentibus conspicuis $1 \mathrm{~mm}$ longis, fructus 5-6 mm longi $5 \mathrm{~mm}$ lati calycis reliquiae conspicuae. - Type: $S A R$ 25080 (Banyeng ak Nudong) (holo L, sh. 107500; A, K, L, SAN, SAR, SING).

Innovations glabrous. Branchlets absent. Petioles narrowly winged, $6-16 \mathrm{~cm}$ by $3 \mathrm{~mm}$, hirsutulous. Leaves linear-lanceolate, $28-33$ by $5-6 \mathrm{~cm}, 5-6$ times as long as wide, $2-4$ times as long as the petioles, base decurrent, margin entire, ciliolate, pergamentaceous (i.s.), underneath hirsutulous, 3-plinerved, suprabasal acrodromous, first pair of primaries $50 \mathrm{~mm}$ away from the base, distalmost primaries $50 \mathrm{~mm}$ away from the preceding pair (the submarginal vein), submarginal vein conspicuous, secondary nerves conspicuous, 20-25 pairs, angle of divergence acute wide, tertiary nerves conspicuous. Bracts $1 \mathrm{~mm}$ long. Flowers absent, born on fascicles on old wood. Hypanthium urceolate to campanulate, $4 \mathrm{~mm}$ long, glabrous. Sepals $1 \mathrm{~mm}$ long, teeth conspicuous, $1 \mathrm{~mm}$ long. Fruit 5-6 by $5 \mathrm{~mm}$, glabrous, red, calyx teeth persistent, crowning the fruit conspicuously, prolonged by a caducous slender hair, pedicels in fruit 25-35 mm long, glabrous; inside filled with jelly.

Distribution - Endemic of Sarawak: 4th Div., Lambir National Park.

Habitat - Nearby river.

Collector's notes - Climbing $3 \mathrm{~m}$ high in a tree. Fruits red.

Notes - Named after its distinctive crowned fruits, adorned by very conspicuous calyx remnants.

Only known from the type.

8. Heteroblemma decurrens (Cogn.) Cámara-Leret, Ridd.Num. \& Veldk., comb. nov.

Medinilla decurrens Cogn. in A.DC., Mon. Phan. 7 (1891) 591. — Type: Beccari PB 4016 (holo Fl; BR).

Innovations glabrescent. Branchlets striate, glabrous, up to 10 $\mathrm{mm}$ diam. Petioles winged, $5-18.5 \mathrm{~cm}$ by $2-4 \mathrm{~mm}$, glabrous (rarely pilose). Leaves elliptic to lanceolate, $10-31$ by $9-17$ $\mathrm{cm}, 2-3.4$ times as long as wide, 1.5-2.8 times as long as the petioles, base decurrent, margin laxly serrulate, ciliolate, apex acuminate, pergamentaceous (i.s.), underneath glabrous (rarely pilose), 5-7-plinerved, basal acrodromous, first pair of primaries 5-15 $\mathrm{mm}$ away from the base, distalmost primaries $10-30 \mathrm{~mm}$ away from the preceding pair, submarginal vein conspicuous, secondary nerves conspicuous, 25 pairs, angle of divergence from midvein acute wide, tertiary nerves conspicuous. Bracts $0.5-1.5 \mathrm{~mm}$ long. Flowers born in dense fascicles on old wood, pedicels $10-15 \mathrm{~mm}$ long, pale red, glabrous. Mature floral buds $8-9$ by 3-4 $\mathrm{mm}$. Hypanthium urceolate to campanulate, $3 \mathrm{~mm}$ long, orange or pale red, glabrous (rarely pilose). Sepals 0.5 $\mathrm{mm}$ long, teeth absent, glabrous. Petals $6-7 \mathrm{~mm}$ long, yellow or pink, outside finely papillose. Filaments $2-3.5 \mathrm{~mm}$ long. Anthers 4-5 mm long, creamy, lateral appendages not recurved, 0.25 $\mathrm{mm}$ long, dorsal spur triangular to lanceolate, 1-2 $\mathrm{mm}$ long. Style 5-6 mm long, creamy or white, stigma white. Fruit 5-7 by $4-6 \mathrm{~mm}$, pale yellow to orange, smooth, glabrous, calyx teeth inconspicuous or absent; pedicels in fruit 15-40 mm long, green, glabrous; inside filled with jelly, seeds c. $1 \mathrm{~mm}$ long, yellow (i.s.).

Distribution - Malaysia: Sarawak, Brunei (Temburong Distr.: Kuala Belalong).

Habitat - Clay rich alluvium along streams, river bank, in occasionally flooded riverine forest, 25-950 m altitude.

Collector's notes - Climber, reportedly up to $10 \mathrm{~m}$ high, stem naked except for the top $1.5 \mathrm{~m}$, greyish, mid-brown, 
chocolate brown. Petiole proximally tinged brown. Leaves when young pinkish (green), later above deep green, beneath paler, drill purple. Flowers cauliflorous. Peduncles pale green, green. Pedicel pale red; hypanthium pale red, orange. Petals pink; pale yellow to yellow flowers as noted for S. 22818 (Jugah ak. Kudi) and Chew Wee-Lek 346 are extremely exceptional in the alliance. Filaments white, anthers cream. Style creamy, white; stigma white. Fruits pale yellow, orange; pedicel green, pale orange

Note -13 collections were seen.

9. Heteroblemma flagellatum (Stapf) Cámara-Leret, Ridd.Num. \& Veldk., comb. nov. - Fig. $2 \mathrm{~h}$

Medinilla flagellata Stapf in Hook.f., Icon. PI. (1895) t. 2411. — Type: Haviland 68 (holo K).

Innovations glabrous. Branchlets striate, glabrous, 6-7 mm diam. Petioles narrowly winged, $5.5-19 \mathrm{~cm}$ by $2-4 \mathrm{~mm}$, hirsutulous. Leaves elliptic to oblong, $21-28$ by $(8.5-) 11.5-16.5 \mathrm{~cm}$, 1.7-2.1 times as long as wide, 1.9-4.4 times as long as the petioles, base decurrent, margin laxly serrulate, ciliolate, apex acuminate, pergamentaceous (i.s.), underneath paler green, hirsute, hairs purplish brown, 7-plinerved, basal acrodromous, first pair of primaries $5-15 \mathrm{~mm}$ away from the base, distalmost primaries $10-30 \mathrm{~mm}$ away from the preceding pair, submarginal vein conspicuous, secondary nerves conspicuous, 20-25 pairs, angle of divergence acute wide, tertiary nerves conspicuous. Bracts 1-1.5 mm long. Flowers born in fascicles on old wood, pedicels 15-20 mm, pinkish red, glabrous. Mature floral buds $9-10$ by $3 \mathrm{~mm}$, purplish or dark pink. Hypanthium urceolate to campanulate, $3.5 \mathrm{~mm}$ long, pinkish red, glabrous. Sepals $1 \mathrm{~mm}$ long, teeth minute, less than $0.5 \mathrm{~mm}$, glabrous. Petals 6-7 mm long, pale to dark pink, outside papillose. Filaments $2 \mathrm{~mm}$ long, white. Anthers $4 \mathrm{~mm}$ long, yellow, lateral appendages not recurved, $0.2 \mathrm{~mm}$ long, dorsal spur triangular to lanceolate. Style $6 \mathrm{~mm}$, white at the base, reddish purple upwards, stigma white. Fruit $7-8$ by $7-8 \mathrm{~mm}$, orange, smooth, glabrous, calyx teeth absent; pedicels in fruit $20-40 \mathrm{~mm}$ long, pinkish red, glabrous; seeds up to $0.5 \mathrm{~mm}$ long, yellow (i.s.).

Distribution - Endemic of Sarawak (1st and 7th Div.).

Habitat - Hill dipterocarp forest, near river, limestone, dark clay soil, $150-365 \mathrm{~m}$ altitude.

Collector's notes - Root climber, up to $8 \mathrm{~m}$ high, flowers 1-2 $\mathrm{m}$ above the ground. Petioles succulent, dark purplish. Leaves above green to dark green, beneath pale green with a purplish brown indument on the nerves. Pedicel pinkish red, dark pink. Flower buds dark pink, purplish. Hypanthium pinkish red, dark pink. Petals pale pink, pinkish white. Filaments white. Stamens arranged in a group so that they are parallel. Filaments white. Anthers yellow, apex and dorsal appendage slightly purplish. Top of ovary pink. Style white at base, upwards reddish purple, stigma white. Berries orange, tasteless.

Note -5 collections were seen.

10. Heteroblemma formanii (Regalado) Cámara-Leret, Ridd.Num. \& Veldk., comb. nov.

Medinilla formanii Regalado, Blumea 35 (1990) 56. - Type: Forman 521 (holo K; BO, L, SING).

Innovations hirsutulous. Branchlets striate, glabrous, c. $6 \mathrm{~mm}$ diam. Petioles terete, $5-9 \mathrm{~cm}$ by $2 \mathrm{~mm}$, pilose. Leaves oblong to lanceolate, $13.5-23.5$ by $4.5-9 \mathrm{~cm}, 2.1-3.6$ times as long as wide, 1.7-4.3 times as long as the petioles, base attenuate, margin entire, ciliolate, apex acuminate, pergamentaceous (i.s.), underneath pilose (on primaries), 5-7-plinerved, basal acrodromous, first pair of nerves branching 5-10 mm away from the base, distalmost primaries $10-30 \mathrm{~mm}$ away from the preceding pair, submarginal vein conspicuous, secondary nerves conspicuous, c. 25 pairs, angle of divergence from midvein acute wide, tertiary nerves conspicuous. Bracts 1-1.5 mm. Flowers born in fascicles on old wood, pedicels 10-20 mm long, glabrous or pilose. Mature floral buds $8-10$ by $3-4 \mathrm{~mm}$. Hypanthium urceolate to campanulate, $3.5 \mathrm{~mm}$ long, glabrous or pilose. Sepals $0.5 \mathrm{~mm}$ long, teeth absent. Petals $5-7 \mathrm{~mm}$ long, purple, outside papillose. Filaments $1.5-2(-3) \mathrm{mm}$ long. Anthers 4-5 mm long, lateral appendages not recurved, up to $0.5 \mathrm{~mm}$, dorsal spur triangular to lanceolate, $1-1.5 \mathrm{~mm}$ long. Style $5-8 \mathrm{~mm}$ long. Fruit $5-7$ by $5-6.5 \mathrm{~mm}$, orange to red, smooth, glabrous, calyx teeth inconspicuous or absent; pedicels in fruit $15-30 \mathrm{~mm}$, glabrous.

Distribution - Endemic of C Kalimantan (Upper Katingan River), E Kalimantan (C Kutei, Tabang, Belajang River; Balikpapan).

Habitat - Dryobalanops or Dipterocarpus mixed forest near river, primary swampy forest, on sandy yellow loam, 0-100 m altitude.

Collector's notes - Epiphytic root climber, lianescent, up to c. $15 \mathrm{~m}$ high, upwards with lateral braches. Plant higher up with lateral branches. Leaves pale green on both sides, nerves brown. Flower (pale) purple. Petals white, pale dirty pinkish, pale pink lilac. Anthers yellowish, yellow. Fruit green white when young, turning mid-orange or red.

Notes - We are unsure of the collections Afriastini 15, Ambriansyah 604, Ambriansyah \& Arbainsyah 1969, Mogea \& De Wilde 4210 \& 4250 . They differ from $H$. formanii by the leaves with an acute base, glabrous underneath, and are (5-)7-9-plinerved.

7 collections were seen.

11. Heteroblemma kemulense (Regalado) Cámara-Leret, Ridd.-Num. \& Veldk., comb. nov. - Fig. $2 f$

Medinilla kemulensis Regalado, Blumea 35 (1990) 57, t. 13. - Type: Endert 4330 (holo K; BO, L).

Innovations glabrous. Branchlets smooth, glabrous, c. $8 \mathrm{~mm}$ diam. Petioles terete, (7.5-) $12-17.5 \mathrm{~cm}$ by $3-5 \mathrm{~mm}$, glabrous. Leaves elliptic, (13.5-)19-23 by (9.5-)14-15 cm, $1.4-1.5$ times as long as wide, 1.3-1.8 times as long as the petioles, base acute, margin laxly serrulate towards the apex, ciliolate, apex acuminate, pergamentaceous (i.s.), underneath glabrous, 9-plinerved, basal acrodromous, first pair of primaries $2-5 \mathrm{~mm}$ away from the base, distalmost primaries $5 \mathrm{~mm}$ away from the preceding pair, submarginal vein conspicuous, secondary nerves conspicuous, c. 25 pairs, angle of divergence acute wide, tertiary nerves conspicuous. Bracts not seen. Flowers born singly in the leaf axils, pedicels $10 \mathrm{~mm}$ long, glabrous. Mature floral buds absent. Fruit c. 11 by $10 \mathrm{~mm}$, green (unripe), rugose or slightly ribbed, glabrous, calyx teeth inconspicuous or absent; pedicels in fruit c. 20 mm, glabrous; inside filled with jelly, seeds $0.7 \mathrm{~mm}$ long.

Distribution - Endemic of Kalimantan, W Kutai, near Mt Kemul.

Habitat - Primary forest, 1600 m altitude.

Collector's notes - Climber. Frit green.

Note - Only known from the type.

12. Heteroblemma loratum (Stapf) Cámara-Leret, Ridd.-Num. \& Veldk., comb. nov. - Fig. $2 \mathrm{~g}$

Medinilla lorata Stapf in Hook.f., Icon. PI. (1895) t. 2417. - Type: Haviland 1785 (holo K, barcodes K000277066, -067).

Innovations hirsutulous. Branchlets striate, glabrous, c. $7 \mathrm{~mm}$ diam. Petioles terete, $3.5-13 \mathrm{~cm}$ by $2-4 \mathrm{~mm}$, glabrous. Leaves 
lanceolate to linear-lanceolate, $22.5-33$ by $3.5-6.5 \mathrm{~cm}, 4.6-6.6$ times as long as wide, $3-5.6$ times as long as the petioles, base long-attenuate, margin entire, glabrous, apex acute, leathery (i.s.), underneath glabrous, 3-plinerved (rarely 5-), suprabasal acrodromous, first pair of primaries 35-110 mm away from the base, distalmost primaries 30-100 mm away from the submarginal vein, submarginal vein conspicuous, secondary nerves conspicuous, 20-30 pairs, angle of divergence acute wide, tertiary nerves faintly visible to inconspicuous. Bracts $1 \mathrm{~mm}$ long. Flowers born in fascicles on old wood or axillary on young stems, pedicels $10-15 \mathrm{~mm}$ long, glabrous. Mature floral buds $9-11$ by $3 \mathrm{~mm}$. Hypanthium urceolate to campanulate, $3 \mathrm{~mm}$ long, glabrous. Sepals $0.5 \mathrm{~mm}$ long, teeth minute, 0.25-0.4 $\mathrm{mm}$ long, glabrous. Petals 6-7 mm long, pink, outside finely red-papillose. Filaments $3 \mathrm{~mm}$ long. Anthers 5-6 mm long, lateral appendages not recurved, $0.3 \mathrm{~mm}$ long, dorsal spur triangular to lanceolate, $1 \mathrm{~mm}$ long. Style 6-7 mm long. Fruit 6 by $5-6 \mathrm{~mm}$, green (unripe), smooth, glabrous, calyx teeth persistent; pedicels in fruit $20-30 \mathrm{~mm}$ long, glabrous; inside filled with jelly, seeds up to $1 \mathrm{~mm}$, yellow (i.s.)

Distribution -- Endemic of Sarawak (1st and 4th Div.; Serian, Bt. Gaharu)

Habitat - Primary forest on yellow clay, near river, up to $660 \mathrm{~m}$ altitude.

Collector's notes - Climber, up to $3 \mathrm{~m}$. Flowers scattered on middle (older) leaf bearing part, pinkish in bud. Stigma violet. Immature fruit pale green, green.

Notes - We are not sure whether Church et al. 348, 409, and Hansen 1230 are conspecific or perhaps represent a proper species. They differ by having 5-7-plinerved leaves, basal acrodromous venation, acute leaf bases and their distribution, and are found in W Kalimantan. Collectors have noted for this: Climber, $3.5 \mathrm{~m}$ long. Leaves above glossy green, beneath pale green, venation very prominent, brownish purple, sunken above; secondary nerves parallel, widely spaced. Pedicels green. Hypanthium pale green. Petals white, white with pink tinge, pale pink. Filaments yellow near apex. Style purple. Fruit orange.

11 collections were seen.

13. Heteroblemma sandakanense (Regalado) Cámara-Leret, Ridd.-Num. \& Veldk., comb. nov.

Medinilla sandakanensis Regalado, Blumea 35 (1990) 63, f. 15. - Type: SAN 20602 (Patrick Ping Sam) (holo K; L, SAN).

Innovations glabrous. Branchlets pustulate, glabrous, c. $8 \mathrm{~mm}$ diam. Petioles terete, $7-12.5 \mathrm{~cm}$ by $3-5 \mathrm{~mm}$, glabrous. Leaves oblong to lanceolate, $23.5-26.5$ by $7-8.5 \mathrm{~cm}, 2.9-3.8$ times as long as wide, 2.1-3.8 times as long as the petioles, base acute, margin entire, glabrous, apex acuminate, pergamentaceous (i.s.), underneath glabrous, 5-plinerved, basal acrodromous, first pair of primaries $2-3 \mathrm{~mm}$ away from the base, distalmost primaries $10-20(-50) \mathrm{mm}$ away from the preceding pair, submarginal vein inconspicuous, secondary nerves conspicuous, 20-25 pairs, at a right angle of divergence from the midvein, tertiary nerves faintly visible to inconspicuous. Bracts $1 \mathrm{~mm}$ long. Flowers unknown, born in fascicles on old wood, pedicels glabrous. Hypanthium urceolate to campanulate, glabrous. Fruit 6 by $5 \mathrm{~mm}$, yellow, smooth, glabrous, calyx teeth absent; pedicels in fruit $25-30 \mathrm{~mm}$ long, glabrous.

Distribution - Endemic of Sabah (Sepilok FR).

Habitat - Primary forest near stream, at low altitude.

Collector's notes - Climber. Fruit yellow.

Note - Only know from the type. Jaheri 18 (BO), from Kalimantan possibly belongs here, but it has shorter pedicels and bristly fruits (Regalado 1990: 65).
14. Heteroblemma serpens (Stapf) Cámara-Leret, Ridd.-Num. \& Veldk., comb. nov. - Fig. 2c

Medinilla serpens Stapf, Icon. PI. (1895a) t. 2411. - Type: Haviland's collector 551 (holo K, barcodes K000277072, -073; SING).

Innovations hirsute. Branchlets pustulate, glabrous, 7-8 mm diam and up to $10 \mathrm{~m}$ in length. Petioles terete, $9-31.5 \mathrm{~cm}$ by 2-6 mm, hirsutulous. Leaves broadly elliptic to elliptic, 13-27 by $12-23 \mathrm{~cm}, 0.9-1.5$ times as long as wide, $0.7-1.8$ times as long as the petioles, base cordate, margin laxly serrulate, ciliolate, apex acuminate, pergamentaceous (i.s.), underneath hirsute, 9-plinerved, campylodromous, first pair of primaries $0-5 \mathrm{~mm}$ away from the base, distalmost primaries $5 \mathrm{~mm}$ away from the preceding pair, submarginal vein conspicuous, secondary nerves conspicuous, 20-25 pairs, angle of divergence from midvein acute wide, tertiary nerves conspicuous. Bracts 1-2 $\mathrm{mm}$ long. Flowers born in dense fascicles, on old wood or axillary on young stems, pedicels $10-15 \mathrm{~mm}$ long, hirsute. Mature floral buds $9-10$ by 3-4 $\mathrm{mm}$. Hypanthium urceolate to campanulate, $3 \mathrm{~mm}$ long, pinkish green, hirsute. Sepals 0.5-1 $\mathrm{mm}$ long, teeth conspicuous, $0.5-1 \mathrm{~mm}$ long, crowned with a 2-3 mm hair. Petals 6-7 mm long, pale pink or pale red, outside papillose. Filaments 2-3 mm long, white. Anthers $4-5 \mathrm{~mm}$ long, yellow, lateral appendages not recurved, $0.5 \mathrm{~mm}$ long, dorsal spur $1 \mathrm{~mm}$ long, triangular to lanceolate. Style $6-8 \mathrm{~mm}$ long, dark pink. Fruit $5-6$ by $5 \mathrm{~mm}$, orange to brown, smooth, glabrescent, calyx teeth persistent; pedicels in fruit $15-30 \mathrm{~mm}$ long, pinkish, glabrescent.

Distribution - Sumatra (Riau Arch: Tudjuh Island), Sarawak (1st Div.), Sabah (Tambunan Distr.).

Habitat - On trees or rocks, limestone hills, only one reference to altitude: $460 \mathrm{~m}$ altitude.

Collector's notes - Creeping herb (!), climber to a height of $7 \mathrm{~m}$, or creeper. Cauliflorous from ground level to top. Leaves beneath pinkish. Pedicels pink, hairy. Hypanthium pinkish green, hairy. Petals pale red, pale pink, whitish pink. Filaments white, anthers yellow. Style pink, dark pink. Fruits brown, orange; pedicles pinkish.

Note -11 collections were seen.

Acknowledgements (especially by RCL) Dr. Max M.J. van Balgooy contributed with his expertise in the generic identification of the incoming Melastomataceae. Prof. Pieter Baas was very kind in pointing out some key literature in regards to vestiture and plant anatomy. Dr. Wim Vink was helpful with my doubts on the subject of domatia. Dr. Paul Keßler on collecting methods and their influence on herbarium material. Dr. Marco Roos in the administrative issues concerning the thesis. Dr. Frits A.C.B. Adema for his help in searching localities. Ms. Anita V.M. Walsmit Sachs-Jansen was extremely kind in preparing the illustrations and initiating me in botanical illustration. In the early stages of the revision valuable advice was given by the late Dr. Rein C. Bakhuizen van den Brink f.

We all are also grateful to the directors and curators of the following herbaria who on very short notice were able to send on loan their valuable material or send high resolution images: $\mathrm{AAU}, \mathrm{BM}, \mathrm{C}, \mathrm{E}, \mathrm{FI}, \mathrm{K}, \mathrm{M}$, and SING

JFV visited SAR in 2012 and thanks its staff for their generous assistance.

\section{REFERENCES}

Almeda F. 1989. New species and taxonomic notes on Mexican and Central American Melastomataceae. Proceedings of the California Academy of Sciences 46, 9: 209-220.

Almeda F. 2001. Three new Mesoamerican species of Topobea (Melastomataceae). Brittonia 53, 1: 157-166.

Averyanov LV, Phan KL, Nguyen TH, Do TD. 2003. Highland vegetation and flora of Van Ban District, Lao Cai Province in northern Viet Nam. Turczaninowia 6, 4: 47-86.

Baker EG. 1924. Dr. H.O. Forbes's Malayan plants. Journal of Botany 62, Suppl. 1: 40 
Bakhuizen van den Brink Jr RC. 1943. A contribution to the knowledge of the Melastomataceae occurring in the Malay Archipelago, especially in the Netherlands East Indies. Thesis, Utrecht. - For the complicated history of this publication, see Stafleu \& Cowan (Taxonomic Literature, ed. 2, 1 (1976) 106-107). Preprint of the next two, which were published using the original type set:

Bakhuizen van den Brink Jr RC. 1946. Recueil des Travaux Botaniques Néerlandais 40: 1-391.

Bakhuizen van den Brink Jr RC. 1947. Mededeelingen van het Botanisch Museum en Herbarium van de Rijks Universiteit te Utrecht 91: 1-391.

Benson WW. 1985. Amazon ant-plants. In: Prank GT, Lovejoy TE (eds), Amazonia: 239-266. Pergamon Press.

Blume CL. 1849. Museum botanicum 1: 19. La Lau, Leiden.

Bremer K. 1988. Melastomataceae. In: Dassanayake MD (ed), A revised handbook to the flora of Ceylon 6: 198-199. Amerind Publishing Co., New Delhi \& Balkema, Rotterdam.

Cabrera M, Jaffe K. 1994. A trophic mutualism between the myrmecophytic Melastomataceae Tococa guianensis Aublet and an Azteca ant species. Ecotropicos 7, 2: 1-10.

Clausing G, Meyer K, Renner SS. 2000. Correlations among fruit traits and evolution of different fruits within Melastomataceae. Botanical Journal of the Linnean Society 133: 303-326.

Clausing G, Renner SS. 2001a. Evolution of growth form in epiphytic Dissochaeteae (Melastomataceae). Organisms Diversity \& Evolution 1: 45-60.

Clausing G, Renner SS. 2001b. Molecular phylogenetics of Melastomataceae and Memecylaceae: implications for character evolution. American Journal of Botany 88: 486-498.

Cogniaux CA. 1891. Melastomataceae. In: De Candolle A, Monographiae phanerogamarum 7: 591. Masson, Paris.

Gleason HA. 1939. The genus Clidemia in Mexico \& Central America. Brittonia 3: $97-140$

\section{INDEX TO COLLECTIONS}

$\begin{array}{ll}\text { Heteroblemma } & \\ \text { alt }=H . \text { alternifolium } & \text { crd }=H . \text { cordatum } \\ \text { bar }=H . \text { barbatum } & \text { cro }=H . \text { coronatum } \\ \text { bis }=H . \text { bisetosum } & \text { dec }=H . \text { decurrens } \\ \text { cap }=H . \text { capillipes } & \text { fla }=H . \text { flagellatum } \\ \text { cle }=H . \text { clemensiae } & \text { for }=H . \text { formanii }\end{array}$

Achmad 355: alt - Aet \& Idjan $825(\mathrm{~V})$ : bar - Afriastini 15: for - Ambriansyah 604: for - Ambriansyah \& Arbainsyah 1969: for - Atkins et al. 563: alt.

Beaman 7080: alt - Beccari PB 2000: alt; PB 4016 (T): dec - Boyce et al. 425: dec-Brooks \& Hewitt s.n. September 1908: lor - BRUN 491 (Ashton): alt; 3106 (Pukol): alt; 17519 (Ahmad et al.): alt; 17926 (Ariffin Kalat et al.): alt - Burley, Tukirin et al. 469: alt; 1186: alt; 3155 (T): crd - Butt 8288: alt - BW 8404 (Vink): bar.

Chew WL 346: dec; 1005: alt - Chew WL et al. 44: alt - Church et al. 1955: alt - Clemens 3829 (T): cle; 21595: alt; 26059: alt; 31321: alt; 31522: alt; 32389: alt - Coode et al. 6406: alt - Curtis 3294: alt.

De Wilde \& De Wilde-Duyfjes 19399: alt; 19897: alt; 19986: alt.

Elmer 21594: alt - Endert $4330(\mathrm{~T})$ : kem.

Forbes $2342(\mathrm{~T})$ : bis - Forman $521(\mathrm{~T})$ : for.

Geh \& Samsuri 905: alt.

Hallier f. 520: alt; 2833: alt; 3314: alt - Hansen 26: alt; 65: alt; 615: fla; 876: fla; 962: fla - Haviland 68 (T): fla; 701: ser; 1682: lor; 1785 (T): lor; 3133 : ser; 3388: lor; 3633: ser - Haviland's collector 551 (T): ser - Haviland \& Hose 3632: alt.

Iboet 82: ant.

Jeremy 14232: alt - Johns 7509: alt.

Keith 5246: alt - Kiew KBH 47: alt - King's Collector 1814 (ST): alt - Kohawa

\& Hotta 1006: alt; 1592: alt - Kostermans 10446: for.

Lam $663(\mathrm{~T})$ : bar.

Mogea 4210: for; 4250: for - MS. 1182 (Shah \& Sidek): alt; 1415 (Shah): alt; 3579 (Shah \& Samsuri): alt; 5722 (Sands et al.): alt - Murata et al. B-3030: alt; B-3118: alt.

NGF 42780 (Henty et al.): bar - Nielsen et al. 1054: alt - Nooteboom 1124: alt. Ohai 3718: alt.

Parris 24/85: alt - Poilane 29857: alt.

Ridley s.n. 1890: ser; July 1893: ser; 2933: alt; 14104: alt.
Hickey LJ. 1973. Classification of the architecture of dicotyledonous leaves. American Journal of Botany 60: 17-33.

Huxley CR. 1986. Evolution of benevolent ant-plant relationships. In: Jupiter B, Southwood R (eds), Insects and the plant surfaces: 257-282. Edward Arnold, London.

Jacobs M. 1968. List of genera for which domatia are on record: 1-19. Mimeograph, Rijksherbarium, Leiden.

King G. 1900. Materials for a flora of the Malayan Peninsula. Journal of the Asiatic Society of Bengal. Part 2. Natural History 69: 60.

Nadkarni NM. 1981. Canopy roots: convergent evolution in rainforest nutrient cycles. Science 214: 1023-1024.

Pemberton RW, Turner CE. 1989. Occurrence of predatory and fungivorous mites in leaf domatia. American Journal of Botany 76: 105-112.

Regalado Jr, JC. 1990. Revision of Medinilla (Melastomataceae) of Borneo. Blumea 35: 5-70.

Renner SS. 1993. Phylogeny and classification of the Melastomataceae and Memecylaceae. Nordic Journal of Botany 13: 519-540.

Stapf O. 1895a. Medinilla serpens Stapf. In: Hook.f., Icones Plantarum: t. 2411.

Stapf O. 1895b. Medinilla lorata Stapf. In: Hook.f., Icones Plantarum: t. 2417 Van Steenis CGGJ. 1981. Rheophytes of the world: an account of the floodresistant flowering plants and ferns and the theory of autonomous evolution: xiv, 407. Sijthoff \& Noordhoff, Alphen aan den Rijn, etc.

Van Steenis CGGJ. 1987. Rheophytes of the world: supplement. Allertonia 4: $267-330$.

Van Vliet GJCM. 1981. Wood anatomy of the palaeotropical Melastomataceae. Blumea 27: 422-424, t. 1-3, f. 1-17.

Wurdack JJ. 1953. A revision of the genus Brachyotum (Tibouchineae-Melastomataceae). Memoirs of the New York Botanical Garden 8: 352.

Wurdack JJ. 1986. Atlas of hairs for Neotropical Melastomataceae. Smithsonian Contributions to Botany 63: 1-80.

$\begin{array}{rlrl}\text { kem } & =H . \text { kemulense } & & (\mathrm{ST})=\text { syntype } \\ \text { lor } & =H . \text { loratum } & (\mathrm{T})=\text { type } \\ \text { san } & =H . \text { sandakanense } & (\mathrm{V})=\text { voucher } \\ \text { ser }=H . \text { serpens } & & \end{array}$

S. 2810 (Anderson): alt; 12139 (Ashton): dec; 12912 (Anderson): ser; 16662 (Paie \& Ashton): lor; 22818 (Jugah): dec; 24380 (Jugah): dec; 25141 (Anderson): ser; 27474 (Erwin \& Paul): fla; 27728 (Smith): cap; 28337 (Anderson \& Paie): alt; 33273 (Tong \& Banyeng): dec; 33990 (Chai): alt; 34673 (Chai): alt; 35651 (Ilias \& Azahari): alt; 36279 (Ilias Paie) (T): cap; 36954 (Martin \& O.): alt; 37559 (Chai et al.): cap; 38613 (Lee B.): ser; 40260 (George): dec; 41034 (Paie): alt; 41909 (Lee B.): ser; 42846 (George et al.): alt; 45296 (Dyg Awa \& Paie): lor; 45358 (Lee B.): dec; 46900 (Dyg Awa \& Yii P.C): cap; 46996 (Awa \& Paie): ser; 48370 (Yii Puan Ching): alt; 49466 (Mohtar et al.): alt; 49694 (Mohtar \& Othman Is.): alt; 50062 (Dyg Awa \& B. Lee): dec; 51408 (Mohtar): dec; 53648 (Ching): alt; 54780 (Lee B.): dec; 56872 (Ching): dec; 62921 (Runi et al.): alt; 66556 (Yahud Hj Wat et al.): cap; 90301 (Kamarudin et al.): alt; 91003 (Kiew et al.): alt; 95792 (Julia et al.): cap - SAN 20602 (Patrick Ping Sam) (T): san; 34104 (Aban): alt; 68354 (Talip \& Terimiji): alt; 82506 (Cockburn): alt; 84854 (Cockburn): alt; 85133 (Stone): alt; 90679 (Patrick et al.): alt; 94499 (Aban G.): alt; 104265 (Krispinus): alt; 119044 (Donggop \& Gambio): alt; 128277 (Krispinus): alt; 128361 (Sumbing): alt - SAR 25080 (Banyeng ak Nudong) (T): cro - Scortechini 80: alt; 86 (ST): alt; 88: alt; 130 (NOT 150; ST): alt - SF 6200 (Sinclair): alt; 10393 (Henderson): alt; 14827 (Boden Kloss): alt; 30127 (Corner): alt; 32048 (Kiah): alt; 32456 (Corner): alt; 32755 (Corner): alt; 36301 (Spare): alt; 38804 (Sinclair et Kiah): alt; 40448 (Sinclair et al.): alt - Soedarsono 214: alt; 378: alt - Stevens et al. 521: alt.

Torquebiau et al. 463: alt; 3598: alt.

Van Balgooy 3531: alt - Van Valkenburg et al. 1086: alt - Veldkamp 7902: alt - VH 640 (Averyanov et al.): bis; 2911 (Averyanov et al.): bis; 3112 (Averyanov et al.): bis; 3493 (Averyanov et al.): bis.

Wong KM 668: alt.

Yalin Surunda 58: alt.

Zainudin 4611: cap. 